\title{
Student Voice in an Extended Curriculum Programme in the Era of Social Media: A systematic Review of Academic Literature
}

\author{
Joshua Ebere Chukwuere ${ }^{1}$ \\ ${ }^{1}$ Department of Information Systems, North-West University, South Africa \\ Correspondence: Joshua Ebere Chukwuere, Department of Information Systems, North-West University, South \\ Africa. \\ Received: August 18, 2020 \\ Accepted: September 21, 2020 \\ Online Published: October 14, 2020 \\ doi:10.5430/ijhe.v10n1p147 \\ URL: https://doi.org/10.5430/ijhe.v10n1p147
}

\begin{abstract}
Student voice in this digital age and across higher learning institutions is increasing exponentially with the function of social media. Student voice provides a vibrant communication pathway to extended curriculum programme students in higher education institutions. Social media ensures active participation of extended curriculum programme students in generating views and ideas that define the higher learning environment and experience towards better learning conditions and outcomes. A systematic literature review was used in gathering scientific papers through trusted academic databases. The systematic literature review was conducted between the period of 1 April 2019 and 28 September 2019, by looking into the contents of articles covering the current research objectives. The study's findings show that social media provides an effective and instant spread of the extended curriculum programme students' voice across higher education learning institutions. It also allows the students in the extended curriculum programme to engage with each other and the institutional management promptly. Social media promotes extended curriculum programme students' voice in reaching the right audience at the right time. The results of this study are key for extended curriculum programme students, lecturers, and university management in understanding and applying social media effectively and in bringing transformation to South African higher education institutions and beyond.
\end{abstract}

Keywords: social media, extended curriculum programme, student voice, higher education institutions, student union, extended curriculum programme student voice

\section{Introduction}

Social media (SM) provides cutting-edge communication channels and voice for the young and old, especially extended curriculum programme students. The advent of social media is influencing higher educational institutions (HEIs) and academic lives (Zachos, Paraskevopoulou-Kollia \& Anagnostopoulos, 2018); higher institutions are exploiting the platform in engaging with students and promoting academic and social engagement. Students are seen as the main voice for social discourse and movement in bringing change to HEIs (Nguyen, 2019). The student voice (SV) is heard through the student union or associations. Since the advent of social media platforms, the platforms are used by student unions to engage and organize students for actions such as protests, mobilizations, and others. Social media provides a voice for many students, especially the extended curriculum programme (ECP) students in developing countries, such as in the case of South Africa (SA). Most South African higher education institutions (SAHEIs) offer extended curriculum programmes (ECPs) that aim at providing students with additional academic and curriculum support such as tutorials, mentoring, guidance and assistance to improve the success and pass rate of students in English language, computer literacy, mathematics, and others. The programme has been offered to regular degree and diploma students, which leads to an additional one year of study. Over the years, ECPs have grown and have graduated students in various fields of study.

ECP students are likely to withdraw from their academic journey if no adequate or extra support has been provided (Sibiya \& Mahlanze, 2018). The supports are because of the inadequacy of facilities at rural schools and the lack of adequate preparation of learners to move from high school to university (Leshoro \& Jacobs, 2019). Despite this fact, much educational support has been provided to assist students in adapting to the university teaching-learning style (Pearce, Campbell, Craig, le Roux, Nathoo \& Vicatos, 2015). The research found that 50\% of the ECP students end their studies halfway (Sibiya \& Mahlanze, 2018). According to researchers, an extended curriculum programme can be regarded as an abridged programme to improve students' overall performance and development as expected by the 
Department of Higher Education and Training (DHET) (Ogude, Meyer, Mwambakana \& Mthethwa, 2019; Hlalele \& Alexander, 2012). However, the impact of social media platforms on ECP students is limited in academic literature and research; this study aims to understand and to provide answers to these questions: What is the role of social media in representing ECP student voices in the SM era? What are the implications of social media on ECP student voice? What are the strategic ways in which social media can be used effectively to promote ECP student voice? The questions need answers from scholars. However, little is known of the impact of social media on SV and especially the voice of ECP students on South African HEIs. Francis and Hardman (2018) maintained that activists' use of social media had been studied in different ways.

The professional development and advancement of teaching and learning in higher educational institutions call for input from collective student voices (Cato, 2018). Student protests around the world are seen in different places, for example, the UK's “Occupy movement" 2011/2012 (Loader et al., 2015), Occupy Wall Street in 2011 (Gerbaudo, 2012), in Spain, the "indignados" movement (Francis \& Hardman, 2018; Gerbaudo, 2012), the Middle East protest (Gerbaudo, 2012; Loader et al., 2015; Francis \& Hardman, 2018), as well as hashtag movements such as \#RhodesMustFall and \#FeesMustFall (Francis \& Hardman, 2018). In all these demonstrations, social media found ways to group and organise people for protests without necessarily having a leader to lead the action (Francis \& Hardman, 2018). Academic studies have been done to understand the role of social media in general public demonstrations, but little is known of the area of representing ECP student voice using social media. The study investigated the role of social media in representing extended curriculum programme student voices in this social media era, the implications of social media on extended curriculum programme student voice, and later on, propose strategic ways to use social media effectively to promote extended curriculum programme student voice.

\section{Method}

According to Okoli and Schabram (2010), the information systems (IS) discipline is still new to the literature review methodology, while disciplines such as health sciences and many other disciplines have long been using the methodology. IS discipline and researchers always follow the conventional research methodologies of using primary empirical data. Literature reviews involve the methods of searching, identifying, developing research objective/s and question/s, collecting data and evaluating existing related research works covering topics and themes under investigation, towards producing new ideas and arriving at conclusions for decision-making (Okoli \& Schabram, 2010; Paré \& Kitsiou, 2017). To Paré and Kitsiou (2017), there are different kinds of "review articles" or literature reviews, for example, narrative, descriptive or mapping, scoping, forms of aggregative, realist, critical reviews, and systematic literature review (SLR).

According to Okoli and Schabram (2010), there are four types of literature reviews: theoretical background covers the literature to guide the researcher to formulate research objective/s or question/s; thesis literature review allows postgraduate students to carry out dissertations or doctoral studies to designate a chapter in the study to discuss existing papers covering the topic under investigation; stand-alone literature reviews (SALR) or narrative reviews review existing literature papers related to the topic under investigation by searching, collecting data and analysing academic articles, and papers. To discover new ideas and research trends to draw conclusions towards the decision-making, a systematic literature review is a comprehensive review of different publications of the same themes and subject area. Based on the discussion and applications, this study is categorized as a systematic literature review study.

As a systematic literature review, this study used accredited scientific papers covering student voice (SV), ECP in South Africa, the role of social media in representing ECP student voice in this SM era, the implications of social media on ECP student voice, and strategic ways in using social media effectively to promote ECP student voice. The keywords searched on the Internet were "student voice", or "social media", or "extended curriculum programme" through Google Scholar, ResearchGate, and other trusted academic databases between the period of 1 April 2019 and 28 September 2019. These searches generated several publications based on the categorised keywords following the PRISMA principle. According to Tang, Bie, Park and Zhi (2018) and Wang, McKee and Torbica (2019), the PRISMA principles were followed to screen and determine the publications used in the study. Table 1 presents some keywords and authors screened based on the publication abstract, introduction, and content of their articles in line with the study's topic and objectives. A total of 200 academic papers were collected, analysed, and reviewed in the study. The PRISMA principle followed selection $(n=130)$, screening $(n=90)$, qualification $(n=50)$ and used $(n=20)$ (Tang et al., 2018; Wang et al., 2019). 
Table 1. Keywords selected

\begin{tabular}{lll}
\hline N & Keywords & Authors \\
\hline 7 & Student voice & $\begin{array}{l}\text { Cato (2018), Garwe (2015), Walker \& Logan (2008), Wilde (2016), Zou \& } \\
\text { Lambert (2017), Nguyen (2019), Pennington et al. (2017). }\end{array}$ \\
& $\begin{array}{l}\text { Cato (2018), Garwe (2015), Walker \& Logan (2008), Wilde (2016), Zou \& } \\
\text { Lambert (2017), Nguyen (2019), Pennington et al. (2017). }\end{array}$ \\
& $\begin{array}{l}\text { Social media } \\
\text { Extended curriculum } \\
\text { programme }\end{array}$ & $\begin{array}{l}\text { Sibiya \& Mahlanze (2018), Pearce et al. (2015), Leshoro \& Jacobs (2019), } \\
\text { Rollnick (2010), Ogude et al. (2019), Halele \& Alexander (2012). }\end{array}$
\end{tabular}

Furthermore, the number of articles used in Table 1 was based on the keywords that directly relate to the study and serving the overall objectives. The excluded articles failed to cover or discuss student voice, ECP student voice, social media, higher education institutions, and student union in relation to the study topic and objectives. Instead, the articles excluded discussed other aspects not related to the study.

\section{Literature Review}

\subsection{Extended Curriculum Programme (ECP)}

South African (SA) HEIs are striving to provide improved quality, world-class, standardised, as well as innovative and equal education to all, including ECP students. The South African society is divided between the advantaged and disadvantaged populations. ECPs were designed to accommodate students who might be disadvantaged to gain access to the university (Ogude et al., 2019; Rollnick 2010). According to Basitere and Ivala (2017), ECP students are enrolled in the university with lower matric grades, such as in the Chemical Engineering programme, with a 50\% pass in Physical Sciences and Mathematics. South African HEIs provide an environment where creative ideas and young professionals are developed.

ECP is a programme designed to assist students in transit into the university proper; therefore, the programme has a university 'credit-bearing' status (Ogude et al., 2019). As a transition programme, students are enrolled in their desired university programme at the end of the ECP. Extended curriculum programmes by nature aim at bridging access to university mainstream programmes; it comes with an additional year of study for the students. Furthermore, Ogude et al. (2019) argued that other forms of programmes exist, such as augmented programmes and foundation programmes, which are university-access programmes with the aim to transit students into the university. Foundation programmes are a year non-credit bearing programme with modules that are different from the mainstream academic modules, while augmented programmes are modified academic programmes that allow students to finish longer than mainstream programmes (Rollnick, 2010, Ogude et al. 2019). Every ECP is an "access programme" into the university irrespective of the name, which also aims for "academic development" towards inclusive education in SA (Hlalele \& Alexander, 2012).

HEIs in South Africa can be regarded post-18 years of learning environment, categorised into the universities, technical vocational education training (TVET) colleges, and universities of technology (UoT), which award degrees and diplomas to students (Boateng \& Amankwaa, 2016). The environment also produces students with social, economic and political (SEP) mindedness in participating in political and non-political issues and debates (Loader, Vromen, Xenos, Steel \& Burgum, 2015). The researchers further believe that HEI is a breeding ground for like-minded individuals to meet and form a collective voice called student voice (SV), the voice expressed by extended curriculum programme students in HEIs. The voice of the ECP students must be heard widely and clearly in our society and higher institutions. Students' participation is being carried out through the student union towards shaping educational, social, economic, and political ideas broadly. The student unions (SUs) are an essential organisation for ECP students and other students' unification in promoting common understanding among the students and politicisation in contributing to current educational issues and challenges. SUs defend ECP students' interests in bringing about transformation in higher education systems and voicing out of the students' interest in society. SAHEIs consist of different SUs, such as South African Students' Congress (SASCO), Azanian People's Organisation (AZAPO), South African National Students Congress (SANSCO), National Union of South African Students (NUSAS), Congress of South African Students (COSAS), Economic Freedom Fighters Students Command (EFFSC), Democratic Alliance Students Organization (DASO) and many more. According to Loader et al. (2015), SUs provide the students with the platform for socialisation and networking to share ideas and interests on educational matters (for example, academic, civil, economic, political issues) and many more. SUs harness students' activism and voice (Garwe, 2017). The SU platform conglomerates student voices (SVs) into one. In addition, the 
service of the SU representatives has been offered to ECP students, and they are free to join the union.

The advent of social media keeps changing the educational, social, and political landscape. Social media now facilitates the organisation of SU for action and politicisation (Loader et al., 2015). Many of the SUs across South African HEIs are very active on social media, using Facebook, Twitter, Instagram, WhatsApp, and many others to engage with students, management, and other stakeholders. While ECP students also use many of these social media platforms to keep an open and active communication line between themselves, their lecturers, and higher institution management, student activism is now mobilised on social media platforms using the hashtag to connect other like-minded individuals (Nguyen, 2019). Their social media presence is visible, but there are questions on the impacts.

\subsection{Student Voice (SV)}

Students (Nguyen, 2019) usually lead social movements. Social, racial, education inequality, student debt, student accommodation, increase in fee, and unemployment lead to student movement protests (Pennington, Mokose, Smith \& Kawanu, 2017). According to Walker and Logan (2008), every child has the freedom of expression (to seek, speak, receive, and to be heard). Every student, including ECP students in the higher education space, has an individual or collective voice of expression. Student voices are expressed within, outside the classroom (university space), and in society. The African Union (AU) 2063 agenda blueprint acknowledged the provision of equal access to sound higher education for all (Garwe, 2017), including students in the ECPs. Governments around the globe work towards the addition of student voices into the learning curriculum (Cato, 2018). The student voice is no longer a street voice. HEI managements are not the sole owner of authorities to guide, lead, and direct; rather, ECP students are now co-opted in the process. ECP students have a unique role in the HEI teaching and learning process by increasing inclusive education and closing the university access gap (Ogude et al. 2019). Vibrant young people's voices, ideas, and concerns must be heard and considered for a better and improved education system in South African HEIs. Since 2015, the call for decolonisation of the education system and free education for all has become the order of the day (Francis \& Hardman, 2018; Chukwuere, 2017; Garwe, 2017). ECP student voice in South African HEIs is getting louder on a daily basis. Furthermore, there is a growing report on student voice (student activism) across the African continent (Garwe, 2017).

According to Wilde (2016), the general student voice ensures that students get actively involved in their education system and in the final decision outcome. Student voice can be regarded as the voice of engagement and involvement of the ECP students in the higher education decision-making process. However, there is no comprehensive definition of student voice in the academic literature (Cato, 2018). Student voice in South Africa aims to provide students' involvement, engagement, transparency, accountability, and many more in HEIs and to empower the students to speak and be heard. It also aims to give ECP students the voice on how their learning will take place, what to learn, and the pedagogy to use. To Wilde (2016) and Garwe (2015), student voice presents students with the opportunity to get involved, participate, engage, lead, learn, reflect, plan, and implement. The concept of SV is the engagement and communication platform for students' opinions and inputs into HEI processes (Zou \& Lambert, 2017). The concept is now part of the HEI process and policymaking (Garwe, 2015); while learning institutions always provide the opportunities to hear students' concerns and negotiate with them. Collinson (2007) suggests that student voice keeps increasing at HEIs across the globe. A sound education system is the one that allows the student's involvement and participation in the teaching and learning process (Zou \& Lambert, 2017). HEIs in South Africa provides the platform to speak out and be listened to (Garwe, 2015). The ability of the students to coordinate and organise their concerns, ideas, opinions, and voice into one can be regarded as student voice.

Students are an integral part of higher education system processes; they bring vibe, skills, money, and intellect (Garwe, 2015). As students are an integral part, it will be unfair to treat them as just the knowledge recipients or receivers. According to Walker and Logan (2008), student voice brings empowerment and opportunities for them to express their beliefs, concerns, opinions, and ideas for better development of their learning environment and their convenience. The researcher further argued that the student voice engages the students and ensures they belong (sense of ownership) in the learning and decision-making processes and enhance the increased relationship between the students, educators and management. As the voices of young people get louder, student voices in HEIs transfer management authorities to the students (Walker \& Logan, 2008). In addition, a practical functionality of academic institutions cannot ignore the student voice and ECP student voice in general.

Extended curriculum programme student voice is heard across different HEIs in South Africa. According to South African History Online (SAHO) (2019), SA universities and many other HEIs have experienced some form of protest, for example, the University of the Witwatersrand (Wits) (2004 \& 2015), Mangosuthu University of Technology, 
Durban (2009), University of Limpopo (2009, 2011 \& 2012), Tshwane University of Technology (TUT) (2012), Vaal University of Technology (VUT) (2014) and many more in recent time. The most popular protest, on the decolonisation and access to higher education, called with the hashtag \#FeesMustFall, \#RhodesMustFall, and many more were all heard widely across social media, printed media, televisions, radios, and other media because of the student voice. \#RhodesMustFall indicates that the higher education status quo must be decolonised, while \#FeesMustFall pushes for access to free and quality education. Both hashtags witnessed massive student protests across different HEIs in South Africa, on the street, and online (social media) (Francis \& Hardman, 2018; Garwe, 2017). Students have expressed their voices for different reasons and demands. Student voice does not just put forward their concerns and views, but it ensures leadership skills, confidence, communication, and others skills are developed, and a student-oriented environment is built (Wilde, 2016). Students' active involvement and engagement will always deliver quality teaching and learning outcomes, improvement, organisational and educational change (Collinson, 2007). Zou and Lambert (2017) suggest that SV presents the need for student views to be heard and listened to, to understand the student's perception in the learning services provided to meet their expectations and needs. The more student voices are heard and involved in the HEI learning process, the better they are motivated to contribute towards improving the quality of education being offered at HEIs.

The active participation and involvement of ECP students in the HEIs have been felt through the students' voice. It provides the communication and engagements between the students, lecturers, and their management, which, in turn, bring about better understanding, sound processes, and achievement of academic mandate and agenda. The voice of the ECP students must be heard, considered, and respected. Students, including ECP students, want their voice to be heard, negotiated, considered, and to affect the outcome in the education management decisions (Walker \& Logan, 2008). Their voice should be heard on new policies, curricula, teaching and learning processes, pedagogy, assessments, technology deployment, staffing, student substructures, learning environment, student accommodation, fees and finance, infrastructure, work opportunities and post-university life (employment), quality of education, equity in education and social justice. These are points of reference upon which ECP student voice has been expressed in South Africa. South African student voice can be categorised into eight different types: express, collaborate, inform, negotiate, consult, involve, empower, and activism (Walker \& Logan, 2008).

\subsection{Social Media and Its Roles in Representing ECP Student Voice in the SM Era}

There is a growing competition among HEIs in enrolling students (Chen \& DiVall, 2018). Student voice plays a significant role in the knowledge-building of institutions. Effective engagement can shape HEI for the better, in transforming the students' experience, the educators, and the education system at large (Walker \& Logan, 2008; Wilde, 2016). Students have turned to social media to air their views and opinions (Francis \& Hardman, 2018). Social media is a connector for student-to-student, student-to-lecturer, student-to-management, student-to-stakeholders, and vice versa (Boateng \& Amankwaa, 2016). Social media promotes engagement, collaboration, and exchange of information and ideas (Tarantino, 2013). In the present society, the role of social media is fuelling social, educational and political engagement, which is gaining attention among scholars (Loader et al., 2015). Social media provides a broader platform for ECP student voice in South Africa to be louder and targeting the right audience.

Social media plays a vital role in ECP students and other young individuals to stimulate engagements and participation in social, educational, and political matters for action (Loader et al., 2015). The researchers further believe that social media allows students to collaborate, interact, and generate content for politicisation. At the same time, Walker and Logan (2008) believed that social networks assist students to actively participate in society and become an active citizen. It also supports ECP students to set mandates, agendas, and negotiate opportunities. Loader et al. (2015) argued that students, including ECP students' participation in social media had been characterised by (1) Cost: the platform is cost-efficient and effective, (2) easy access: it provides quick generation and access to contents, (3) sharing: it promotes easy sharing of contents for wider coverage, (4) ubiquitous: generated contents can be shared and accessed anywhere and anytime with any internet-enabled device. To Chukwuere and Onyebukwa (2017), social media provides a cheaper, accessible, easy to use, instant, and effective platform for single and massive communication to a broader audience. For Boateng and Amankwaa (2016), social media is a platform for young individuals to multitask on a number of daily activities. The platform ensures that ECP students and social voices are being heard wide and clear. It also ensures that students express themselves (speak out) when they see and experience some challenges. According to Nguyen (2019), the student's voice is a voice for change using social media "hashtag activism" to organise demonstrations and protests.

Current ECP students are predominated by digital natives with a vast knowledge of the Internet and other forms of 
digital communication gadgets. Their digital nativeness can be evidently seen on sophistication to access, use, and its application in their personal and academic lives; also, graduates are expected by their employers to be technologically knowledgeable (Griesemer, 2012). As an enabler for students and the human/social voice, the Middle East protest was coordinated on social media (Loader et al. 2015), as well as the 2016 \#FeesMustFall and \#RhodesMustFall campaigns and many others across different educational institutions. The presence of social media towards coordinating the SV and ECP student voice for action cannot be underrated in our HEIs. Extended curriculum programme (ECP) students are being more connected on social media and airing their concerns and ideas, which get louder than ever before.

\subsection{The Implications of Social Media on ECP Student Voice}

The overall implications of social media on extended curriculum programme (ECP) student voice have been categorised into positive and negative. Reports on student voice (activism) across the African continent are growing as a threat towards advancing higher education mandates in producing graduates for national development (Garwe, 2017). Social media is actively changing the educational landscape and extended curriculum programme student voice (ECPSV). The emergence is influencing how extended curriculum programme (ECP) students learn and engage with themselves. Social media promotes communication and transforming how ECP students engage with academic institution management and the public. As an agent of change, the sharing of information, knowledge, and ideas keeps increasing among higher institution ECP students. The use of social media during the 2014/2015 protests in South Africa using the hashtags is highlighting the role of social media in coordinating demonstrations, sharing of information among students and the society at large (Francis \& Hardman, 2018). There are implications of social media in facilitating an extended curriculum programme student voice (ECPSV). A few of these positive implications are as follows:

$\checkmark \quad$ It promotes ECP students involvement and inputs into the affairs of higher education decision-making processes.

$\checkmark \quad$ It facilitates information and knowledge sharing between ECP student, the public, and HEIs management.

$\checkmark \quad$ Instant feedback and engagement.

$\checkmark \quad$ It promotes unlimited access to student voice.

$\checkmark \quad$ It assists the voice of the voiceless ECP student to be heard.

$\checkmark \quad$ It directs the ECP student voice to the right audience at the right time.

$\checkmark \quad$ It assists in coordinating ECP students' movements and unions (associations).

$\checkmark \quad$ It disrupts the universities' traditional authority and provides a voice for the voiceless ECP student in promoting student-oriented higher education (Francis \& Hardman, 2018).

$\checkmark \quad$ It generates first-hand content and reports instantaneously.

$\checkmark \quad$ It provides instant content for discussion, sharing, debate, and knowledge construction on challenges and issues of concerns for students (Francis \& Hardman, 2018).

$\checkmark \quad$ It improves communication, interactions, collaboration, participation, and engagement among ECP students.

$\checkmark \quad$ It defends ECP student voice, student and academic rights, and promotes higher education standards.

Social media presents an open world of engagement for ECP student voice to be heard and a voice for the voiceless, but there are negative consequences associated if misused:

$\checkmark \quad$ Student voice sometimes promotes the disruption of lives and properties.

$\checkmark \quad$ It also promotes violence among students and academic rights.

$\checkmark \quad$ It can promote fake news - people who are not part of the student's voice can hijack the trending posts and stories and turn them into something else.

$\checkmark \quad$ Abuse of freedom of expression - some people can abuse student voice over social media.

$\checkmark$ Cyberbullying - some students may bully others on social media (online).

3.5 Strategic Ways in Using Social Media Effectively in Promoting ECP Student Voice

Across the continent of Africa, the rate of student activism is increasing in the form of student voice, as in the case of South Africa, Nigeria, Egypt, Kenya, Zimbabwe, and many other countries (Garwe, 2017). Globally, student voice actions have been witnessed across the world in efforts to strengthen the students' academics rights and higher 
education standards (Cato, 2018). Student voice allows the participation and engagement of ECP students towards the enrichment of higher education standards.

Student voice does not happen overnight; it is a planned process. For ECP student voice to excel effectively on social media (online environment), the following should be considered:

$\checkmark$ Build a social media presence: In the successful engagement of ECP students, online presence should be planned and implemented with a genuine and coordinated mandate.

$\checkmark$ Develop some soft skills: Good writing, communication, and presentation skills should be incorporated.

$\checkmark$ Students' needs and expectations: Engage the ECP students on topics and issues that directly affect them.

$\checkmark$ Opportunities for participation: Provide opportunities for ECP students to get involved and engage in the dialogue process with university management in letting their voices be heard.

$\checkmark$ Create a hashtag: Hashtag facilitates any comment, post, or story to trend on social media. Let the hashtag speak or explain the issue at hand.

The important role of social media cannot be over-emphasised in the $21^{\text {st }}$ century student voice and student activism. Students remain an important player in ensuring the HEIs deliver their academic mandate. The need and expectations of the students have been addressed through comprehensive student voices. Figure 1 presents the very important role social media plays in advancing ECP student voice in the $21^{\text {st }}$ century (Loader et al., 2015; Walker \& Logan, 2008).

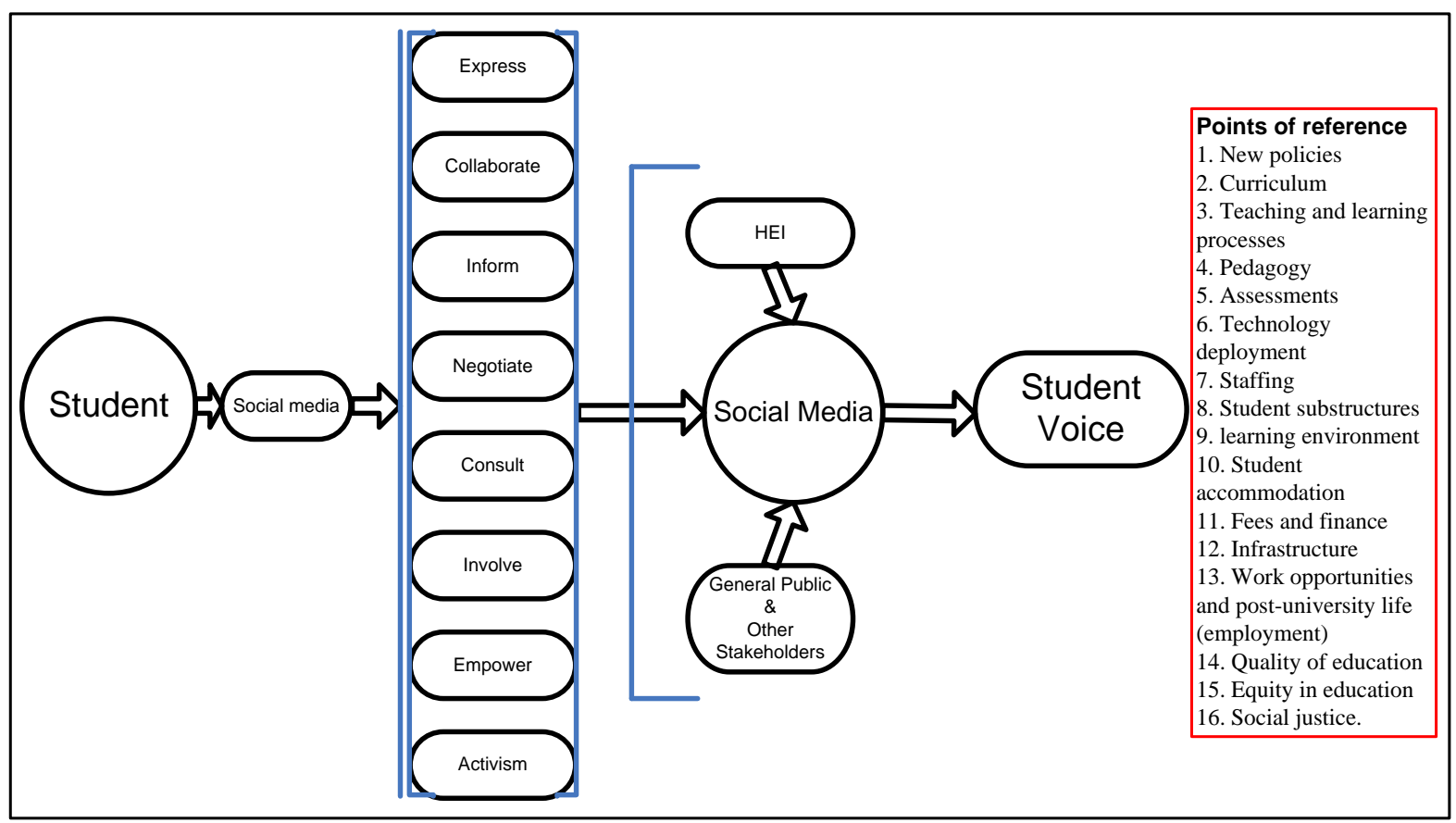

Figure 1. Social media role in advocating extended curriculum programme (ECP) student voice (adapted from Walker \& Logan, 2008)

An indication from Figure 1 directs strategic ways and areas ECP students use social media in promoting their voice. ECP students use the platform to express, collaborate, inform, negotiate, consult, involve, empower, and plan (activism) (Walker \& Logan, 2008). All these activities have been carried out on social media towards achieving ECP student voice. Figure 1 further shows that social media is a mediator between students, HEIs, the general public, and other stakeholders in attaining and addressing different kinds of issues, directly and indirectly, affecting them and society at large.

\section{Findings, Recommendations, and Study Areas for the Future}

Social media plays an important role in social and academic engagement and mobilisation of ECPs. Then, lecturers (university teachers), university managements, and other stakeholders should understand that social media facilitates extended curriculum programme (ECP) student voice in the academic and non-academic environment. 
The study findings show that social media has the potential to provide ECP students with the ability to:

$\checkmark$ own their education and defend its processes.

$\checkmark$ bring innovative ideas, opinions, and solutions.

$\checkmark$ provide boundless voice to ECP students.

$\checkmark$ express views on issues of concern and challenges for attention and action/s.

$\checkmark \quad$ provide an effective and instant spread of student voice across learning institutions.

$\checkmark \quad$ allow the ECP students to engage with themselves and the institution management quickly.

$\checkmark$ make ECP student voice reach the right audience at the right time.

$\checkmark$ express what they need and what their expectations are, and how things should be done in teaching and learning pedagogy.

$\checkmark$ shift from the university management authority's dominance to student-oriented HEIs based on the student voice.

These recommendations should guide all stakeholders on the role of social media on ECP student voice:

$\checkmark \quad$ lecturers and university managements should be aware that ECPs are listening and recording all they say, which can be posted on social media platforms.

$\checkmark \quad$ social media is an open world for ECP students to use.

$\checkmark$ no more boundaries for information and content sharing for the student voice.

$\checkmark$ directive policy framework should be implemented on the student voice on social media.

$\checkmark \quad$ all students should be trained in effective social media usage for personal and academic-related matters.

In the future, research should be done to determine the extent that social media has been used on student voice, in the classroom and society. The negative implications of the student voice in achieving educational transformation and the extent to which ECP student voice is considered by lecturers, university managements, and other stakeholders in achieving quality and inclusive education for all should also be determined.

\section{The Implication of the Study}

Social media platforms assist ECP students in expressing their voice in bringing transformation and innovations in South African HEIs. The results of this study are key for ECP students, lecturers, and university managements in understanding and applying social media effectively and in bringing the transformation to South African HEIs. ECP students will be able to understand that social media allows them to express, collaborate, inform, negotiate, consult, involve, empower, and plan (activism) through active unified voice in the day-to-day or continuous operation of South Africa HEIs. Furthermore, lecturers and university management can understand through this study that student voice cannot be ignored on social media platforms. However, their voice of engagement on social media platforms can be managed effectively and controlled for expectations and needs to be met. In summation, Figure 1 highlights 16 points of reference on the issue that concerns ECP students continuously to express their voice on social media platforms.

\section{Conclusion}

The voices of ECP students and the students in HEIs are being expressed in classrooms, within and outside the university environment through social media platforms. Lecturers and management authorities at HEIs need to understand and appreciate ECP student voice as a means towards the delivery of quality, transformed, and sustainable academic institutions. This study was able to investigate the role of social media in representing extended curriculum programme student voice in this social media era, the implications of social media on extended curriculum programme student voice, and propose strategic ways to use social media effectively to promote extended curriculum programme student voice.

The study provided the findings and implications in highlighting the positive and negative aspect in applying social media platforms in facilitating ECP student voice, and a strategy was developed on the use of social media platforms to promote effective and engaging extended curriculum programme (ECP) student voice within and outside HEIs in the digital age. Scholars should pay attention and investigate more on similar studies in order to promote effective usage of social media platforms in strengthening and engaging with ECP students' productivity. 


\section{References}

Alexander, G., \& Hlalele, D. (2012). University access, inclusion and social justice. South African Journal of Higher Education, 26(3), 487-502.

Basitere, M., \& Ivala, E. (2017). Evaluation of an adaptive learning technology in a first-year extended curriculum programme physics course. South African Computer Journal, 29(3), 15. https://doi.org/10.18489/sacj.v29i3.476

Boateng, R., \& Amankwaa, A. (2016). The impact of social media on student academic life in higher education. Global Journal of Human-Social Science, 16(4), 1-8.

Cato, N. (2018). Student voice in secondary schools: purpose, value and characteristics.

Chen, E., \& DiVall, M. (2018). Social media as an engagement tool for schools and colleges of pharmacy. American journal of pharmaceutical education, 82(4), 6562. https://doi.org/10.5688/ajpe6562

Chukwuere, J. (2017). From decolonisation to digitalisation of education in South Africa. International Journal of Science and Research, 73(12/1). https://doi.org/10.21506/j.ponte.2017.12.15

Chukwuere, J. E., \& Onyebukwa, C. F. (2017, July). New media and politics: An assessment of 2016 South African local government elections. In Proceedings of International Academic Conferences (No. 4607534). International Institute of Social and Economic Sciences. https://doi.org/10.20472/IAC.2017.031.018

Collinson, D. L. (2007). Researching leadership in the learning and skills sector: by the sector, on the sector, for the sector.

Francis, S., \& Hardman, J. (2018). RhodesMustFall: using social media to "decolonise" learning spaces for South African higher education institutions: a cultural historical activity theory approach. South African Journal of Higher Education, 32(4), 66-80. https://doi.org/10.20853/32-4-2584

Garwe, E. C. (2015). Student voice and quality enhancement in higher education. Journal of Applied Research in Higher Education, 7(2), 385-399. https://doi.org/10.1108/JARHE-05-2014-0055

Garwe, E. C. (2017). Student Voice: Embracing Student Activism as a Quality Improvement Tool in Higher Education. Global Voices in Higher Education, 189. https://doi.org/10.5772/intechopen.68669

Gerbaudo, P. (2012). Tweets and the Streets: Social Media and Contemporary Activism. London: Pluto Press. https://doi.org/10.2307/j.ctt183pdzs

Griesemer, J. A. (2012). Using social media to enhance students' learning experiences. Quality approaches in higher education, 3(1), 8-11.

Leshoro, T. M., \& Jacobs, A. (2019). Challenges to admissions in the Extended Curriculum Programme of the Faculty of Business and Management Sciences. South African Journal of Higher Education, 33(1), 173-183. https://doi.org/10.20853/33-1-804

Loader, B. D., Vromen, A., Xenos, M. A., Steel, H., \& Burgum, S. (2015). Campus politics, student societies and social media. The Sociological Review, 63(4), 820-839. https://doi.org/10.1111/1467-954X.12220

Nguyen, M. (2019). The Effects of Social Media and Hashtag Activism on Enhancing Student Voice to Create Institutional Curriculum Changes. https://doi.org/10.18776/tcu/br/4/106

Ogude, N. A., Meyer, I. J., Mwambakana, J., \& Mthethwa, N. E. (2019). Can extended curriculum programmes be improved through engagement with students using appreciative inquiry? South African Journal of Higher Education, 33(4), 219-236. https://doi.org/10.20853/33-4-2835

Okoli, C., \& Schabram, K. (2010). A guide to conducting a systematic literature review of information systems research. https://doi.org/10.2139/ssrn.1954824

Paré, G \& Kitsiou, S. (2017). Chapter 9 Methods for Literature Reviews. In: Lau F, Kuziemsky C, editors. Handbook of eHealth Evaluation: An Evidence-based Approach [Internet]. Victoria (BC): University of Victoria; 2017 Feb 27. Retrieved from https://www.ncbi.nlm.nih.gov/books/NBK481583/

Pearce, H., Campbell, A., Craig, T. S., Le Roux, P., Nathoo, K., \& Vicatos, E. (2015). The articulation between the mainstream and extended degree programmes in engineering at the University of Cape Town: Reflections and possibilities. South African Journal of Higher Education, 29(1), 150-163. https://doi.org/10.20853/29-1-451

Pennington, A., Mokose, M., Smith, M. N., \& Kawanu, Z. (2017). Neoliberalism and the crisis in higher education in 
South Africa: student voice. New Agenda: South African Journal of Social and Economic Policy, 2017(64), 28-32.

Rollnick, M. (2010). Identifying potential for equitable access to tertiary level science: Digging for gold (Vol. 41). Springer Science \& Business Media. https://doi.org/10.1007/978-90-481-3224-9

Sibiya, M. N., \& Mahlanze, H. T. (2018). Experiences of facilitators regarding the extended curriculum programme offered at a higher education institution in the province of KwaZulu-Natal in South Africa. Curationis, 41(1), 1-6. https://doi.org/10.4102/curationis.v41i1.1895

South African History Online (SAHO). (2019). Student protests in democratic South Africa. Retrieved from https://www.sahistory.org.za/article/student-protests-democratic-south-africa

Tang, L., Bie, B., Park, S. E., \& Zhi, D. (2018). Social media and outbreaks of emerging infectious diseases: A systematic review of literature. American journal of infection control, 46(9), 962-972. https://doi.org/10.1016/j.ajic.2018.02.010

Tarantino, K., McDonough, J., \& Hua, M. (2013). Effects of student engagement with social media on student learning: A review of literature. The Journal of Technology in Student Affairs, 1(8), 1-8.

Walker, L., \& Logan, A. (2008). Learner engagement. A review of learner voice initiatives across the UK's education $\begin{array}{lllll}\text { sectors. } & \text { Future } & \text { Lab } & \text { Report. } & \text { Retrieved }\end{array}$ http://www.futurelab.org.uk/resources/documents/other_research_reports/Learner_Engagement.pdf

Wang, Y., McKee, M., Torbica, A., \& Stuckler, D. (2019). Systematic literature review on the spread of health-related misinformation on social media. Social Science \& Medicine, 112552. https://doi.org/10.1016/j.socscimed.2019.112552

Wilde, K. (2016). VicSRC: Student voice and the education state: A guide for Victorian Schools. Connect, (219), 21.

Zachos, G., Paraskevopoulou-Kollia, E. A., \& Anagnostopoulos, I. (2018). Social media use in higher education: A review. Education Sciences, 8(4), 194. https://doi.org/10.3390/educsci8040194

Zou, D., \& Lambert, J. (2017). Feedback methods for student voice in the digital age. British journal of educational technology, 48(5), 1081-1091. https://doi.org/10.1111/bjet.12522

\section{Copyrights}

Copyright for this article is retained by the author(s), with first publication rights granted to the journal.

This is an open-access article distributed under the terms and conditions of the Creative Commons Attribution license (http://creativecommons.org/licenses/by/4.0/). 